\title{
Occurrence of Babesia vogeli, Mycoplasma spp., Ehrlichia canis and Anaplasma spp. in a hospital dog population of western Paraná
}

\section{Ocorrência de Babesia vogeli, Mycoplasma spp., Ehrlichia canis e Anaplasma spp. em uma população hospitalar de cães do Oeste do Paraná}

\author{
Carla Rodrigues Bahiense ${ }^{\text {*; }}$; Aldair Calistro de $\mathrm{Matos}^{2}$; Hugo Luca Abate ${ }^{3}$; Nelson \\ Jesse Rodrigues dos Santos ${ }^{3}$; Odilon Vidotto ${ }^{4}$
}

\section{Highlights:}

Identifies the frequency of B. vogeli, Mycoplasma spp., E. canis, and Anaplasma spp.

Lists Babesia, Ehrlichia, Mycoplasma and Anaplasma diagnostic tools.

Discusses the vector's influence on the low occurrence of $E$. canis.

\begin{abstract}
Ehrlichia canis, Anaplasma platys, and Babesia vogeli are frequently detected in the veterinary routine with varied pathogenesis that can lead to death, mainly in co-infections. Although canine hemotropic mycoplasmas are considered of low clinical importance, they have recently gained prominence in molecular research. The present study aimed to analyze two hospital populations of dogs, randomly selected from the year 2013 and 2015, from the municipalities of Toledo $(n=68)$ and Cascavel $(n=107)$. Direct examination of blood smears, serology, and PCR were used to detect the presence of E. canis, $A$. platys, B. vogeli and Mycoplasma sp. Direct blood smear examination was negative for the investigated agents in all samples. Serum immunochromatography (SensPERT тM, VetAll Laboratories, Korea) in 175 animals showed that only $4 \%(\mathrm{n}=7)$ had anti-E. canis antibodies, while $60 \%(\mathrm{n}=105)$ were positive for Anaplasma sp. All PCR samples were negative for E. canis, while $18.28 \%(\mathrm{n}=32)$ were positive for A. platys, 3.42\% $(\mathrm{n}=6)$ positive for Babesia vogeli, and $7.41 \%(\mathrm{n}=13)$ positive for Mycoplasma sp. The study revealed the presence of A. platys in Toledo and Cascavel by PCR, which accentuates the need to monitor vector populations and usual hosts and to evaluate the potential risk of infection in humans.
\end{abstract}

Key words: Anaplasmosis. Ehrlichiosis. Hemoparasites. Rhipicephalus sanguineus. PCR. Immunochromatography.

\section{Resumo}

Ehrlichia canis, Anaplasma platys e Babesia vogeli são frequentemente detectados na rotina veterinária com patogênese variada que pode levar à morte, principalmente em coinfecções. Embora os micoplasmas

${ }^{1}$ Dra., Universidade Estadual de Londrina, UEL, Londrina, PR, Brasil. E-mail: cbahiense.vet@gmail.com

2 Técnico Responsável, Laboratório de Moléstias Parasitárias, Departamento de Medicina Veterinária Preventiva, UEL, Londrina, PR, Brasil. E-mail: aldair@uel.br

3 Discentes do Curso Doutorado do Programa de Pós-Graduação em Ciência Animal, UEL, Londrina, PR, Brasil. E-mail: hugoabate@gmail.com; nelson.jrsantos@uel.br

4 Prof., Dr., Departamento de Medicina Veterinária, UEL, Londrina, PR, Brasil. E-mail: vidotto@uel.br

Author for correspondence 
hemotrópicos caninos sejam considerados de baixa importância clínica, recentemente ganharam destaque na pesquisa molecular. O presente estudo teve como objetivo analisar duas populações hospitalares de cães, selecionadas aleatoriamente no ano de 2013 e 2015, dos municípios de Toledo (n=68) e Cascavel $(\mathrm{n}=107)$. O exame direto de esfregaços de sangue, sorologia e PCR foram usados para detectar a presença de E. canis, A. platys, B. vogeli e Mycoplasma sp. O esfregaço sanguíneo direto foi negativo para os agentes investigados em todas as amostras. A imunocromatografia sérica (SensPERT TM, VetAll Laboratories, Coréia) em 175 animais mostrou que apenas $4 \%(\mathrm{n}=7)$ tinham anticorpos contra E.canis, enquanto $60 \%(\mathrm{n}=105)$ foram positivos para Anaplasma sp. Todas as amostras de PCR foram negativas para E. canis, enquanto $18,28 \%(\mathrm{n}=32)$ foram positivas para $A$. platys, $3,42 \%(\mathrm{n}=6)$ positivas para Babesia vogeli e 7,41\% $(\mathrm{n}=13)$ positivas para Mycoplasma sp. O estudo revelou a presença de $A$. platys em Toledo e Cascavel por PCR, o que acentua a necessidade de monitorar populações de vetores e hospedeiros usuais e avaliar o risco potencial de infecção em humanos.

Palavras-chave: Anaplasmose. Erliquiose. Hemoparasitas. Rhipicephalus sanguineus. PCR. Imunocromatografia.

\section{Introduction}

Hemoparasitosis is frequent in the veterinary clinic and has a wide geographical distribution, with a more pronounced presence in regions of tropical and subtropical climates, due to the inherent characteristics of the vectors (Belozerov, 1982). It can affect several species, including humans, which endangers public health (Dantas-Torres, Figueredo, \& Brandão, 2006).

Canine monocytic ehrlichiosis (EMC) is caused by the mandatory intracellular bacterium Ehrlichia canis (Kuehn \& Gaunt, 1985), which normally infects members of the Canidae family (Shaw et al., 2005), but has been isolated in humans as well (Perez, Rikihisa, \& Wen, 1996). In Brazil, E. canis has been identified in several states (R. F. C. Vieira et al., 2011) with variable prevalence, which may exceed $70 \%$ of seroprevalence (Melo et al., 2011). The severity of EMC varies according to the strain involved, the host's immune status, and the coexistence of other hemoparasitosis (Sousa et al., 2009). Thus, it may result in the death of the infected animal, which justifies the scientific appeal to preventive methods (Trapp, Messick, Vidotto, Jojima, \& Morais, 2006).

Anaplasma platys, a bacterium that triggers canine cyclic infectious thrombocytopenia (Nair et al., 2016), commonly affects canids, but has already been identified in other mammals such as humans
(Correa et al., 2011; Rufino et al., 2013; ArragaAlvarado et al., 2014). Correa et al. (2011) found A. platys DNA in $13.18 \%$ of domestic cats and suggested it acts as a reservoir, given the absence of clinical signs in positive animals. In Brazil, molecular studies have indicated variable prevalence in dogs, reaching 55\% in Paraná (Ramos et al., 2009). It is assumed that transmission occurs through the tick Rhipicephalus sanguineus (Machado, Dagnone, \& Silva, 2010), despite the experimental failure to reproduce this phenomenon (Simpson et al., 1991).

Canine babesiosis can be caused by Babesia canis, Babesia vogeli, Babesia Rossi, Babesia caballi, Babesia gibsoni, Babesia conradae and Babesia microti-like sp. (Bilic, Kules, Bariac, \& Mrljak, 2018). In Brazil, molecular identification of both B. vogeli (Passos, Geiger, Ribeiro, Pfister, \& Zahler-Rinder, 2005) and B. gibsoni (Trapp et al., 2006) has already been reported. The prevalence of the agent in Brazil can reach $66.9 \%$, as described in Minas Gerais (Dantas-Torres \& Figueredo, 2006). A. P. Costa et al. (2015) demonstrated that among dogs from Maranhão, those from urban areas were twice as likely to be positive and that this fact was associated with a higher prevalence of $R$. sanguineus in the declared urban population. In Paraná, blood samples from 282 dogs with clinical signs of babesiosis showed that 105 had DNA from B. vogeli (Jojima et al., 2008), whose vector 
is $R$. sanguineus (Schnittger, Rodriguez, FlorinChristensen, \& Morrison, 2012). Moreover, the $B$. gibsoni vector has already been reported in Brazil, namely in Londrina (Trapp et al., 2006; Jojima et al., 2008). The pathogenesis of babesiosis depends on the species involved (Bourdoiseau, 2006), with B. vogeli generally being asymptomatic in adult dogs (Schnittger et al., 2012).

Mycoplasma sp., also known as hemotropic mycoplasmas or hemoplasms, have a higher prevalence when other tick-transmitted pathogens are present (Roura et al., 2010). A study in Italy showed that the prevalence of the agent increased from the north to the south of the country, the warmest region, suggesting climatic influence (Novacco et al., 2010). In Brazil, a study carried out in Ribeirão Preto, SP demonstrated a low prevalence of the agent with only four positives out of $154 \mathrm{dogs}$ tested (one for 'Candidatus M. haematoparvum' and three for M. haemocanis) (Alves et al., 2014). In the Londrina region, $44.7 \%$ of dogs from rural areas were positive for hemoplasms, of which $35 \%$ were positive for $M$. haemocanis, $20 \%$ were positive for Ca. M. haematoparvum 'and the rest for both agents (R. F. C. Vieira et al., 2015).

Both Mycoplasma sp. and Babesia sp. can be identified by direct microscopy; however, this method has low sensitivity (Bourdoiseau, 2006; Aquino et al., 2016). The different species of Babesia sp. and Mycoplasma sp. can also be identified by PCR (Jojima et al., 2008; T. S. W. J. Vieira et al., 2013) or by real-time PCR (L. M. Costa et al., 2012; Barker et al., 2004).

Even though A. platys and Anaplasma phagocytophilum are routinely diagnosed by light microscopy, this has been replaced by more sensitive and specific techniques, with emphasis on molecular diagnosis (Little, 2010). Traditionally, indirect immunofluorescence (IFAT) has been used to determine antibodies against $E$. canis and, although it can result in false positives (Wen et al., 1997), it is mostly employed to establish prevalence in epidemiological studies. Nevertheless, to nPCR (16S rRNA) and PCR of the disulfide oxidoreductase gene are more indicated to determine the presence of E. canis (Aguiar, Saito, Hagiwara, Machado \& Labruna, 2007), whereas, for A. platys, PCR (16S rRNA) (Eddlestone et al., 2007) or nested PCR (16S rRNA) and nPCR (23SrRNA) (Dahmani, Marié, Mediannikov, Raoult, \& Davoust, 2015) are the best options.

Considering the lack of data on Babesia, Mycoplasma, E. canis, and A. platys in western Paraná, this study aimed to evaluate the occurrence of these hemoparasites in the hospital populations of dogs in the cities of Toledo and Cascavel.

\section{Material and Methods}

\section{Description of the area under study}

A total of 175 dogs from the cities of Cascavel $\left(24^{\circ} \circ 57^{\prime} 21^{\prime \prime} \mathrm{S} ; 53^{\circ} 27^{\prime} 19^{\prime \prime} \mathrm{W}\right)$ and Toledo (24 42 '49" S; $53^{\circ} \circ 44^{\prime} 35^{\prime \prime} \mathrm{W}$ ) were evaluated, located in Western Paraná (Figure 1) and characterized by a humid subtropical climate (Instituto Agronômico do Paraná [IAPAR], 2016). Both municipalities have well-defined seasons, Cascavel with a minimum of $-4.2{ }^{\circ} \mathrm{C}$ and a maximum of $37.6{ }^{\circ} \mathrm{C}$ (IAPAR, 2016) and Toledo with a minimum of $-2.7^{\circ} \mathrm{C}$ and a maximum of $38.0^{\circ} \mathrm{C}$ (Instituto Nacional de Meteorologia, 2016). 


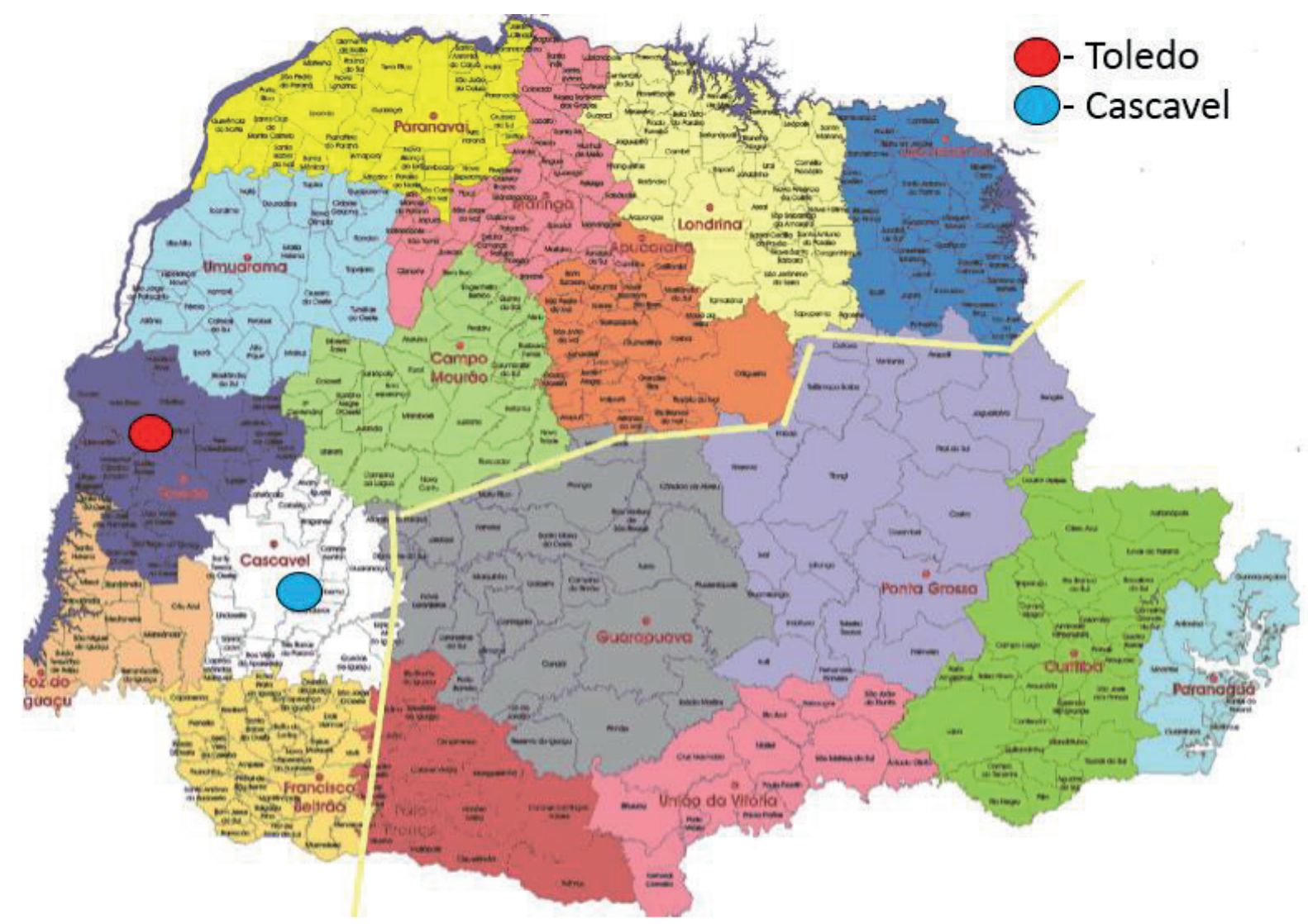

Figure 1. Location of the cities of Toledo and Cascavel located in the western region of the state of Paraná, Brazil, where blood samples were collected from dogs in 2013 and 2015.

\section{Sampling of animals}

The animals were randomly selected from two hospital populations, from the Pontifical Catholic University of Paraná (PUCPR) and from the Assis Gurgacz Faculty (FAG), in the Toledo and Cascavel regions, respectively. The sample number was calculated using the Working in Epidemiology 2.0 software, based on the number of annual consultations ( $\mathrm{n}=1500)$, a $95 \%$ confidence interval, a minimum prevalence of $2.5 \%$, and an error of $5 \%$. With 5\% significance, the software revealed 116 was the minimum sample number to represent the population. However, we analyzed samples from $175 \mathrm{dogs}$, totaling $68 \mathrm{dogs}$ from Toledo and 107 from Cascavel, submitted to descriptive statistical analysis and inference through the chi-square test or Fisher's exact test, with $\alpha=5 \%$ and $95 \%$ confidence interval. The samples were collected at random on average, we selected one in five consultations with an indication of venipuncture during the years 2013 and 2015. The project followed the guidelines of the National Council for Animal Control and Experimentation, with approval by the research ethics committee in the use of animals under protocol No. 1005 / 15- PUCPR.

\section{Blood collection}

Venous blood samples were fractionated so that $2 \mathrm{~mL}$ were transferred to tubes containing EDTA and $3 \mathrm{~mL}$ packed in tubes without anticoagulant. A $1 \mathrm{~mL}$ aliquot of red blood cells and leukocytes was frozen at $-20^{\circ} \mathrm{C}$ for molecular analysis. 


\section{DNA extraction and PCR}

The sample DNA was extracted from 200 $\mu \mathrm{L}$ of blood cell concentrate using the PureLink Genomic DNA Mini Kit ${ }^{\circledR}$ (Invitrogen) according to the manufacturer's guidelines, which resulted in an eluate of $50 \mu \mathrm{L}$ that was frozen at $-20{ }^{\circ} \mathrm{C}$ until its amplification.

Among the samples, 50\% were tested using PCR for the glyceraldehyde-3-phosphate dehydrogenase (GAPDH) gene to ensure that the extraction occurred correctly, as previously described (Birkenheuer, Levy, \& Breitschwerdt, 2003).

The E. canis virB9 gene (Q6XXL7_EHRCA) was amplified with the primers ECAVB9-F and ECAVB9-R (Felek, Huang \& Rikihisa, 2003) and the 16S rRNA gene from $A$. platys with the primer PLATYS-F and PLATYS R (Silva et al., 2012).

The $B$. vogeli $18 \mathrm{~S}$ rRNA gene was amplified with the primers CAN $626 \mathrm{R}$ and CAN $172 \mathrm{~F}$ (Ribeiro et al., 2017), whereas the 16S rRNA gene for the group of hemotropic mycoplasmas with the aid of the primers 16S_HAEMOforw and 16S_HAEMOrev (Hoelzle et al., 2011).

The amplifications were performed with a volume of $25 \mu \mathrm{L}$, containing $3 \mu \mathrm{L}$ of DNA, $1.0 \mu \mathrm{L}$ of each primer, $0.25 \mu \mathrm{L}$ of Taq polymerase, and 12.5 $\mu \mathrm{L}$ of MIX 1.5. For E. canis the thermocycler was programmed to perform 35 cycles $\left(91^{\circ} \mathrm{C}\right.$ for 1 '; $94^{\circ} \mathrm{C}$ for 1 '; $58^{\circ} \mathrm{C}$ for 1 '; $72^{\circ} \mathrm{C}$ for 1 ') followed by an extension cycle $72^{\circ} \mathrm{C}$ by 7 '; thermal cycles for $A$. platys consisted of 35 cycles $\left(91^{\circ} \mathrm{C}\right.$ by 1 '; $94^{\circ} \mathrm{C}$ by 1 '; $60^{\circ} \mathrm{C}$ by 1 '; $72^{\circ} \mathrm{C}$ by $1^{\prime}$ ') followed by an extension cycle $72^{\circ} \mathrm{C}$ by 7 '; for B. canis the thermocycler was programmed to perform 35 cycles $\left(94^{\circ} \mathrm{C}\right.$ for 5 '; $94^{\circ} \mathrm{C}$ for 1 '; $60^{\circ} \mathrm{C}$ for 1 '; $72^{\circ} \mathrm{C}$ for $1^{\prime}$ ) followed by an extension cycle $72^{\circ} \mathrm{C}$ by 7 '; the thermal cycles for hemoplasma consisted of 32 cycles $\left(94^{\circ} \mathrm{C}\right.$ by 2 '; $95^{\circ} \mathrm{C}$ by 30 "; $50^{\circ} \mathrm{C}$ by $30^{\prime \prime} ; 68^{\circ} \mathrm{C}$ by 1 ' 30 ") followed by an extension cycle $72^{\circ} \mathrm{C}$ for 7 '.
We used ultrapure water as a negative control and DNA samples from agents previously stored in the laboratory as a positive one, as used in previous experiments (Silva et al., 2012). The products of the PCR amplifications were subjected to electrophoresis on an agarose gel with $6 \mu \mathrm{g} / \mathrm{mL}$ of SYBR ${ }^{\circledR}$ Safe DNA Gel Stain (Invitrogen, CA, USA) and $1.5 \%$ bromophenol blue dye for later observation under UV light.

\section{Hemoparasite Serology and Research}

Serological tests for E. canis and Anaplasma sp. were performed using a commercial rapid immunochromatography test (SensPERTTM, VetAll Laboratories, South Korea) on the 175 serum samples, according to the manufacturer's specifications.

The hemoparasite test was carried out in 10 fields on the fringe of each blood smear stained with Romannowsky.

\section{Results and Discussion}

\section{Molecular detection}

None of the 175 samples from Cascavel and Toledo, Paraná, were positive for E. canis (Table 1), despite its high occurrence in most countries (R. F. C. Vieira et al., 2011) and some medical records that report vector infestation. E. canis DNA studies, in random samples of canines in the State of Paraná, showed a $16.4 \%$ of positive results that in Jataizinho, a city located $400 \mathrm{~km}$ to the north (Silva et al., 2012). In Maringá, located $280 \mathrm{~km}$ to the north, and Londrina, located $380 \mathrm{~km}$ to the north, animals suspected of EMC were sampled and analyzed by PCR, which identified the DNA of $E$. canis in $51.8 \%$ and $21.7 \%$ of the dogs, respectively (Souza et al., 2011; Dagnone, Morais, Vidotto, Jojima \& Vidotto, 2003). 
Table 1

Occurrence of Ehrlichia canis and Anaplasma platys using PCR and serology in dogs from a hospital population in the municipalities of Cascavel and Toledo, Paraná, 2015.

\begin{tabular}{ccccc}
\hline Resultados & $\begin{array}{c}\text { PCR } \\
\text { E. canis }\end{array}$ & $\begin{array}{c}\text { Immunochromatography } \\
\text { E. canis }\end{array}$ & $\begin{array}{c}\text { PCR } \\
\text { A. platys }\end{array}$ & $\begin{array}{c}\text { Immunochromatography } \\
\text { Anaplasma spp. }\end{array}$ \\
\hline Canine & 0 & 7 & 32 & 105 \\
Positive & $(0 \%)$ & $(4 \%)$ & $(18.28 \%)$ & $(60 \%)$ \\
\hline Canine & 175 & 168 & 143 & 70 \\
Negative & $(100 \%)$ & $(96 \%)$ & $(81.71 \%)$ & $(40 \%)$ \\
\hline Total & 175 & 175 & 175 & 175 \\
\hline
\end{tabular}

In the present study, $37.28 \%(44 / 118)$ of the animals with anemia and/or thrombocytopenia were negative for PCR. This result is in line with that obtained by Gottlieb et al. (2016), who reported that among 58 animals suspected of hemoparasitosis, none of them were positive for E. canis in Rio Grande do Sul. Furthermore, Malheiros, Costa, Amaral, Sousa, \& André (2016) did not obtain any positive results in 110 dogs from Passo Fundo, RS. Our study disagrees with the estimate that one in five thrombocytopenic animals is infected with the agent (Dagnone et al., 2003), which may result from the low sample number of thrombocytopenic $\operatorname{dogs}(n=32 / 27.11 \%)$, laboratory characteristics most striking of the infection found in $100 \%$ of the positive dogs in the PCR in Botucatu (Ueno et al., 2009), and in $66.7 \%$ of the dogs in a survey in Brasília (Cesar, 2008). This discrepancy may be explained by classifying the study areas according to their climates, which suggests that this there are different species of the $R$. sanguineus vector (one temperate and the other tropical), as described by (Moraes et al., 2011)

Of the 175 animals analyzed by PCR for $A$. platys, $18.28 \%(\mathrm{n}=32)$ were positive (Table 1$)$. Similar studies have shown lower prevalence, as observed in the Pantanal, where $7.19 \%$ of the dogs were positive (Melo et al., 2016) and in Cuiabá, with $9.1 \%$ of positive results (Witter et al., 2013). There was a significant difference $(p=0.000028)$ between the two populations, demonstrating that the dogs of Cascavel (28.03\%) were more likely to present the DNA of the pathogen when compared to animals from Toledo (2.94\%).

Some populations of $R$. sanguineus collected in Montevideo (Uruguay), Santa Fe (Argentina), and Cachoeira do Sul (RS; Brazil) are not competent as vectors of E. canis (Moraes et al., 2015). Based on the fact that Cachoeira do Sul is $750 \mathrm{~km}$ south of Cascavel and that a significantly higher prevalence of this pathogen has been reported in the canine population located approximately that same distance to the north (Silva et al., 2010), we suggest that the area under study belongs to a transition band between different $\mathrm{R}$. sanguineus populations that can be competent or not to act as $E$. canis vectors. This may be caused by the subtropical climate of Cascavel and Toledo, a classification in which cities where the existence of these non-competent populations was characterized (Moraes et al., 2015).

Even in the absence of ectoparasites studies in the region and the possibility of other ixodid ticks acting as vectors (Johnson et al., 1998), $R$. sanguineus is probably the most frequent because $83 \%$ of the population was declared urban and $74 \%$ of these inhabited the interior of their homes. This fact strengthens the theory of a regional vector populations unable to transmit the agent, since a portion of the individuals had vector infestation. A previous study in Argentina showed that A. platys prevalence in dogs was three times higher than 
that of E. canis (Eiras, Craviotto, Vezzani, Eyal \& Baneth, 2013). This result is consistent with our work, in which the prevalence of A. platys was higher since no sample was positive for E. canis, yet another evidence that may be associated with vector characteristics.

We found evidence of B. canis DNA in $3.42 \%$ of the dogs, and their blood samples were analyzed using PCR with specific primers for the 18S rRNA gene. When comparing to studies with similar conditions, such as random subject collection and PCR as detection method, B. canis prevalence in the present study was lower than that found in Rio de Janeiro (11.9\%) (Vilela et al., 2013), and similar to that observed in Mato Grosso (3.13\%) (Melo et al., 2016). The lower prevalence rates observed in southern regions of Brazil suggest a climatic influence on the vector population, $R$. sanguineus. Although it was isolated in cold climates (Schnittger et al., 2012), this ixodid tick can reproduce up to four generations per year in tropical climatic conditions, which contributes to the population increase (Dantas-Torres \& Figueredo, 2006).

Research based on the IFI for B. vogeli reveals more discrepant data, as is the case of Minas Gerais (18.8\%) (Maia, Costa, Haddad, Passos, \& Ribeiro, 2007) and Londrina (36\%) (Trapp et al., 2009), which is expected due to the presence of antibodies that remain in the bloodstream after the acute phase of the disease persisting in healthy animals. The sample selection of animals suspected of babesiosis demonstrated that only $37.4 \%$ were positive for PCR in Londrina (Jojima et al., 2008), which suggests that even in the face of clinical and laboratory suspicion, differential diagnoses should always be considered.

Only 13 (7.42\%) of the 175 samples subjected to PCR for hemoplasma were positive. The prevalence found in this study was higher than that in Ribeirão Preto $(2.59 \%)$ (Alves et al., 2014), and lower than that observed in the rural area of Londrina (44.7\%) (R. F. C. Vieira et al., 2015). In regions where the presence of the $R$. sanguineus vector is uncommon, hemoplasma infection is rare (Kenny, Shaw, Beugnet, \& Tasker, 2004); however, no studies have attempted to investigate this in the region under study.

\section{Serology}

Only 4\% (7/175) of the analyzed samples presented anti-E. canis antibodies, as assessed by the Sens PERTTM immunochromatography serological test (Table 1). Another serological test based on ELISA ( $3 \mathrm{dx}$ IDEXX) was validated by Harrus et al. (2002), and when comparing it with positive samples in the IFAT, it revealed $100 \%$ specificity and $71 \%$ sensitivity. This low sensitivity was attributed to the titration, indicating the author to repeat the exam in 1-2 weeks to increase the sensitivity of the test. Belanger et al. (2002) performed a similar comparative study with similar results.

In Brazil, the seroprevalence of $E$. canis in regions close to the Equator line reaches $72.5 \%$, as is the case in Paraíba (Azevedo et al., 2011). In Cuiabá, located in the central-west region, seroprevalence is $42.5 \%$ (Silva et al., 2010). Areas even farther from the Equator line showed a seroprevalence of up to $20.4 \%$, as in Guarapuava, a city with subtropical climate located $250 \mathrm{~km}$ from the area under study (Dobrowolski, Gheller, , Carrasco \& Seki, 2015). Bowman et al. (2008) demonstrated when analyzing different regions of the USA, that seroprevalence increased in southern regions. Therefore, our results corroborate the recurrent correlation of E. canis seroprevalence to climatic factors.

We found antibodies to Anaplasma sp. in 60\% (105) of the 175 samples evaluated, and only 11 of them were also positive for $A$. platys, as determined by PCR (Table 1). Some hypotheses to explain this discrepancy between positive animals detected by PCR and serology could be suggested. The fact that samples are randomly collected decrease the probability of these animals being in the acute 
phase, resulting in a PCR false negative, since $\operatorname{IgG}$ in dogs can be found as early as seven days after infection (Nair et al., 2016). In addition, platelet parasitemia is cyclical, with platelet inclusions appearing for a short period during the acute phase of the disease. Eddlestone et al. (2007) used realtime PCR to analyze leukocyte samples as well as and splenic and medullary tissue from dogs that had been experimentally infected with $A$. platys. These animals were monitored for 28 days and tested for A. platys DNA between the 4th and the 14th day after infection. The authors concluded that the subsequent negative tests could be the result of the sequestration of infected platelets by phagocytic cells of the reticulum endothelial system.

The manufacturer of the commercial ELISA 3 Dx (IDEXX) reports the possibility of crossreaction between $A$. phagocytophilum and A. platys, which could justify the high number of positives. However, Ferreira et al. (2008) tested 16 PCR positives for $A$. platys with ELISA, resulting in a negative result for $A$. phagocytophilum, which may also be due to the absence of antibodies in the initial stage of the disease. Although the kit they utilized was not from IDEXX, it was also based on immunochromatography.

\section{Hematozoa research}

Direct examination of all analyzed samples $(\mathrm{n}=$ 118) was negative for both $E$. canis and A. platys. The negative results for $E$. canis can be supported by the absence of DNA in $100 \%$ of these samples and by the low sensitivity of the technique, which is a dependent examiner. Evidence of $A$. platys was not observed in any of the 34 samples that contained the pathogen's DNA, which is explained by the non-specificity of platelet inclusions and the low or absent parasitemia (Ferreira et al., 2008; Machado et al., 2010). Direct examination can thus result in false negatives, as in the case of a $21 \%$ occurrence of A. platys against $55 \%$ positives identified by nPCR in the same sample number (Ramos et al., 2009), and false positives, as pointed out in a study where only $44.4 \%$ of the samples with platelet inclusions were also positive when analyzed by PCR for $A$. platys (Correa et al., 2011).

\section{Conclusion}

Using molecular techniques, our work demonstrated the presence of A. platys, Mycoplasma sp., and B. vogeli in domestic animal dogs from the Cascavel and Toledo region of Western Paraná.

No sample was positive in the direct blood smear examination, evidencing the low sensitivity of this technique to diagnose asymptomatic animals.

This study contributes to the epidemiology of dog hemoparasites, since it reports the occurrence of E. canis, A. platys, B. vogeli, and hemoplasma in dogs domiciled in the western region of Paraná.

\section{References}

Aguiar, D. M., Saito, T. B., Hagiwara, M. K., Machado, R. Z., \& Labruna, M. B. (2007). Diagnóstico sorológico de erliquiose canina com antígeno brasileiro de $E$. canis. Ciência Rural, 37(3), 796-802. doi: 10.1590/ S0103-84782007000300030

Alves, T. B., Faggion, S. A., Santos, E. V., Roberto, P. G., França, S. C., Fachin, A. L., \& Marins, M. (2014). Real-time PCR-based study of haemothropic mycoplasmas in dogs from Ribeirão Preto, Brazil. Archieves Veterinary Medicine, 46(2), 333-336. doi: 10.4067/S0301-732X2014000200021

Aquino, L. C., Kamani, J., Haruna, A. M., Paludo, G. R., Hicks, C. A., Helps, C. R., \& Tasker, S. (2016). Analysis of risk factors and prevalence of hemoplasma infection in dogs. Veterinary Parasitology, 221, 11117. doi: 10.1016/j.vetpar.2016.03.014

Arraga-Alvarado, C. M., Qurollo, B. A., Parra, O. C., Berrueta, M. A., Hegarty, B. C., \& Breitschwerdt, E. B. (2014). Case report: molecular evidence of Anaplasma platys infection in two women from Venezuela. American Journal of Tropical Medicine and Hygiene, 91(6), 1161-1165. doi: 10.4269/ajtmh. 14-0372

Azevedo, S. S., Aguiar, D. M., Aquino, S. F., Orlandelli, R. C., Fernandes, A. R. F., \& Uchôa, I. C. P. (2011). 
Soroprevalência e fatores de risco associados à soropositividade para Ehrlichia canis em cães do semiárido da Paraíba. Brazilian Journal of Veterinary Research and Animal Science, 48(1), 14-18. doi: 10.11606/S1413-95962011000100002

Barker, E. N., Tasker, S., Day, M. J., Warman, S. M., Woolley, K., Birtles, R.,... Helps, C. R. (2004). Development and use of real-time PCR to detect and quantify Mycoplasma haemocanis and Candidatus Mycoplasma haematoparvum in dogs. Veterinary Microbiology, 140(1-2), 167-170. doi: 10.1016/j. vetmic. 2009.07 .006

Belanger, M., Sorenson, H. L., France, M. K., Bowie, M. V., Barbet, A. F., Breitschwerdt, E. B., \& Alleman, A. R. (2002). Comparison of serological detection methods for diagnosis of Ehrlichia canis infections in dogs. Journal of Clinical Microbiology, 40(9), 3506-3508. doi: 10.1128/JCM.40.9.3506-3508.2002

Belozerov, V. N. (1982). Diapause and biological rhythms in ticks. In: Obenchain, F.D., Galun, R., Physiology of ticks (pp. 469-500). Pergamon: Oxford.

Bilic, P., Kules, J., Bariac, R. R., \& Mrljak, V. (2018), Canine Babesiosis: where do we stand? Acta Veterinaria, 68(2), 127-160. doi: 10.2478/acve2018-0011

Birkenheuer, A. J., Levy, M. G., \& Breitschwerdt, E. B. (2003) Development and evaluation of a seminested PCR for detection and differentiation of Babesia gibsoni (Asian genotype) and B. canis DNA in canine blood samples. Journal of Clinical Microbiology, 41(2003), 4172-4177. doi: 10.1128/JCM.41.9.4172

Bourdoiseau, G. (2006). Canine babesiosis in France. Veterinary Parasitology, 138(1-2), 118-125. doi: 10. 1016/j.vetpar.2006.01.046

Bowman, D., Little, S. E., Lorentzen, L., Shields, J., Sullivan, M. P., \& Carlim, E. P. (2008). Prevalence and geographic distribution of Dirofilaria immitis, Borrelia burgdorferi, Ehrlichia canis and Anaplasma phagocytophilum in dogs in the United States: results of a national clinic-based serologic survey. Veterinary Parasitology, 160(1-2), 138-148. doi: 10.1016/j.vetpar.2008.10.093

Cesar, M. F. (2008). Ocorrência de Ehrlichia canis em cães sintomáticos atendidos no Hospital Veterinário da Universidade de Brasília e análise de variabilidade em regiões genômicas de repetição. Dissertação de mestrado, Universidade de Brasília, Brasília, GO, Brasil.

Correa, E. S., Paludo, G. R., Scalon, M. C., Machado, J. A., Lima, A. C. Q., Pinto, A. T. B.,... Albernaz,
A. B. (2011). Molecular investigation of Ehrlichia spp. and Anaplamsa platys in domestic cats: clinical signs, hematological and biochemical alterations. Pesquisa Veterinária Brasileira, 31(10), 899-909. doi: 10.1590/S0100-736X2011001000011

Costa, A. P., Costa, F. B., Labruna, M. B., Silveira, I., Moraes, J., Fo., Soares, J. F.,... Guerra, R. M. S. N. C. (2015). A serological and molecular survey of Babesia vogeli, Ehrlichia canis and Rickettsia spp. among dogs in the state of Maranhão, northeastern Brazil. Brazilian Journal of Veterinary Parasitology, 24(1), 28-35. doi: 10.1590/S1984-29612015008

Costa, L. M., Jr., Zahler-Rinder, M., Ribeiro, M. F. B., Rembeck, K., Rabelo, E. M. L., Pfister, K., \& Passos, L. M. F. (2012). Use of a real-time PCR for detecting subespécies of Babesia canis. Veterinary Parasitology, 188(1-2), 160-163. doi: 10.1016/j. vetpar.2012.03.015

Dagnone, A. S., Morais, H. S. A., Vidotto, M. C., Jojima, F. S., Vidotto, O. (2003). Ehrlichiosis in anemic, thrombocytopenic, or tick-infested dogs from a hospital populations in South Brazil. Veterinary Parasitology, 117, 285-290. doi: 10.1016/j. vetpar.2003.10.001

Dahmani, M., Marié, J. L., Mediannikov, O., Raoult, D., \& Davoust, B. (2015). First identification of Anaplasma platys in the blood of dogs from French Guiana. Vector-borne and Zoonotic Diseases, 15(2), 170-172. doi: 10.1089/vbz.2014.1720

Dantas-Torres, F., \& Figueredo, L. A. (2006). Canine babesiosis: a Brazilian perspective. Veterinary Parasitology, 141(3-4), 197-203. doi: 10.1016/j. vetpar.2006.07.030

Dantas-Torres, F., Figueredo, L. A., \& Brandão, S. P., Fo. (2006). Rhipicephalus sanguineus (Acari: Ixodidae), the brown dog tick, parasiting humans in Brazil. Revista da Sociedade Brasileira de Medicina Tropical, 39(1), 64-67. doi: 10.1590/S003786822006000100012

Dobrowolski, E. C., Gheller, J. M., Carrasco, A. O. T., \& Seki, M. C. (2015). Soroprevalência e fatores de risco da Ehrlichia canis em cães da região de Guarapuava. Anais do Congresso Brasileiro de Medicina Veterinária e I Congresso Sul-Brasileiro, Curitiba, PR, Brasil, 42.

Eddlestone, S. M., Gaunt, S. D., Neer, T. M., Boudreaux, C. M., Gill, A., Haschke, E., \& Corstvet, R. E. (2007). PCR detection of Anaplasma platys in blood and tissue of dogs during acute phase of experimental infection. Experimental Parasitology, 115(2), 205210. doi: 10.1016/j.exppara.2006.08. 006 
Eiras, D. F., Craviotto, M. B., Vezzani, D., Eyal, O., \& Baneth, G. (2013). First description of natural Ehrlichia canis and Anaplasma platys infections in dogs in Argentina. Comparative Immunology, Microbiology and Infectious Diseases, 36(2), 169173. doi: 10.1016/j.cimid.2012.11.008

Felek, S., Huang, H., \& Rikihisa, Y. (2003). Sequence and expression. Analysis of virB9 of the type IV secretion system of Ehrlichia canis strains in ticks, dogs, and cultured cells. Infections and Immunity, 71(10), 6063-6067. doi: 10.1128/IAI.71.10.60636067.2003

Ferreira, R. F., Cerqueira, A. M. F., Pereira, A. M., Velho, P. B., Azevedo, R. R. M., Rodrigues, I. L. F., \& Almosny, N. R. P. (2008). Avaliação da ocorrência de reação cruzada em cães PCR-positivos para Anaplasma platys testados em ELISA commercial para detecção de anticorpos de Anaplasma phagocytophilum. Revista Brasileira de Parasitologia Veterinária, 17(1), 5-8. Recuperado de http:// www.redalyc.org/ articulo.oa? $\mathrm{id}=397841469001$

Gottlieb, J., André, M. R., Soares, J. F., Gonçalves, L. R., Oliveira, M. T., Costa, M. M.,... Vieira, M. I. B. (2016). Rangelia vitally, Babesia spp. and Ehrlichia spp. In dogs in Passo Fundo, state of Rio Grande do Sul, Brazil. Brazilian Journal of Veterinary Parasitology, 25(2), 172-178. doi: 10.1590/S198429612016041

Harrus, S., Alleman, A. R., Bark, H., Mahan, S. M., \& Waner, T. (2002). Comparison of three enzymelinked immunosorbant assays with the indirect immunofluorescent antibody test for the diagnosis of canine infection with Ehrlichia canis. Veterinary Microbiology, 24(86), 361-368. doi: 10.1016/s03781135(02)00022-6

Hoelzle, K., Winkler, M., Kramer, M. M., Wittenbrink, M. M., Dieckmann, S. M., \& Hoelzle, L. (2011). Detection of Candidatus Mycoplasma haemobos in cattle with anaemia. The Veterinary Journal, 187(3), 408-410. doi: 10.1016/j.tvj1.2010.01.016

Instituto Agronômico do Paraná (2016). Cartas climatológicas do Paraná.

Instituto Nacional de Meteorologia (2016). Normais climatológicas do Brasil 1981-2010.

Johnson, E. M., Ewing, S. A., Barker, R. W., Fox, J. C., Crow, D. W., \& Kocan, K. M. (1998). Experimental transmission of Ehrlichia canis (Rickettsiales: Ehrlichieae) by Dermacentor variabilis (Acari: Ixodidae). Veterinary Parasitology, 74(2-4), 277288. doi: 10.1016/S0304-4017(97)00073-3
Jojima, F. S., Garcia, J. L., Vidotto, M. C., Balarin, M. R. S., Fabretti, A. K., Gasparin, M. R.,... Vidotto, O. (2008). Ocorrência e caracterização molecular de espécies de Babesia em cães de uma população hospitalar de Londrina. Revista Brasileira de Parasitologia Veterinária, 17(1), 277-283.

Kenny, M. J., Shaw, S. E., Beugnet, F., \& Tasker, S. (2004). Demonstration of two distinct hemotropic mycoplasmas in French dogs. Journal of Clinical Microbiology, 42(11), 5397-5399. doi: 10.1128/ JCM. 42.11.5397-5399.2004

Kuehn, N. F., \& Gaunt, S. D. (1985). Clinical and hematologic findings in canine ehrlichiosis. Journal American Veterinary Medical Association, 186(4), 355-358.

Little, S. (2010). Ehrlichiosis and anaplasmosis in dogs and cats. Veterinary of Small Clinical Animals, 40(6), 1121-1140. doi: 10.1016/j.cvsm.2010.07.004

Machado, G. P., Dagnone, A. S., \& Silva, B. F. (2010). Anaplasmose trombocítica canina - uma breve revisão. Revista Cientifica Eletrônica de Medicina Veterinária, 8(15), 1-12. Retrieved from http://faef. revista.inf.br/imagens_arquivos/arquivos_destaque/ 8J0itKMfE0OXrcN_2013-6-25-16-43-23.pdf

Maia, M. G., Costa, R. T., Haddad, J. P. A., Passos, L. M. F., \& Ribeiro, M. F. B. (2007). Epidemiological aspects of canine babesiosis in the semiarid area of state of Minas Gerais, Brazil. Preventive Veterinary Medicine, 79(2-4), 155-162. doi: 10.1016/j. prevetmed.2006.11.013 Retrieved from http://faef. revista. inf.br/imagens arquivos/arquivos destaque /8J0itKMfE0OXrcN_2013-6-25-16-43-23.pdf

Malheiros, J., Costa, M. M., Amaral, R. B., Sousa, K. C. M., \& André, M. R. (2016). Identification of vectorborne pathogens in dogs and cats from Southern Brazil. Ticks and Ticks-borne Diseases, 7(5), 893900. doi: 10.1016/j.ttbdis.2016.04.007

Melo, A. L. T., Martins, T. F., Horta, M. C., Moraes, J., $\mathrm{F}^{\mathrm{o}}$., Pacheco, R. C., Labruna, M. B., \& Aguiar, D. M. (2011). Seroprevalence and risk-factors to Ehrlichis spp. And Rickettsia spp. In dogs from Pantanal Region of Mato Grosso State, Brazil. Ticks and Tick-borne Diseases, 2(4), 213-218. doi: 10.1016/j. ttbdis.2011.09.007

Melo, A. L. T., Witter, R., Martins, T. F., Pacheco, T. A., Alves, A. S., Chitarra, C. S., Aguiar, D. M. (2016). A survey of tick-borne pathogens in dogs and their ticks in the Pantanal biome, Brazil. Medical and Veterinary Entomology, 30(1), 112-116. doi: 10.1111/ mve. 12139 
Moraes, J., F'., Krawczak, F. S., Costa, F. B., Soares, J. F., \& Labruna, M. B. (2015). Comparative evaluation of the vector competence of four South American populations of the Rhipicephalus sanguineus group for the bacterium Ehrlichia canis, the agent of canine monocytic ehrlichiosis. PLos One, 10(9): e0139386 doi: 10.1371/journal.pone.0139386

Moraes, J., Fo., Marcili, A., Nieri-Bastos, F. A., Richtzenhain, L. J., \& Labruna, M. B. (2011). Genetic analysis of ticks belonging to the Rhipicephalus sanguineus group in Latin America. Acta Tropica, 117(1), 51-55. doi: 10.1016/j. actatropica.2010.09.006

Nair, A. D. S., Cheng, C., Ganta, C. K., Sanderson, M. W., Alleman, A. R., Munderloh, U. G., \& Ganta, R. R. (2016). Comparative experimental infection study in dogs with Ehrlichia canis, E. chaffeensis, Anaplasma platys and A. phagocytophilum. PLoS One, 11(2):e0148239. doi: 10.1371/journal.pone. 0148239

Novacco, M., Meli, M. L., Gentili, F., Marsilio, F., Ceci, C., Pennisi, M. G, Hofmann-Lehmann, R. (2010). Prevalence and geographical distribution of canine hemitropic mycoplasma infections in Mediterranean countries and analysis factors for infection. Veterinary Microbiology, 142(3-4), 276-284. doi: 10.1016/j. vetmic.2009.09.069

Passos, L. M. F., Geiger, S. M., Ribeiro, M. F. B., Pfister, K., \& Zahler-Rinder, M. (2005). First molecular detection of Babesia vogeli in dogs from Brazil. Veterinary Parasitology, 127(1), 81-85. doi: 10.1016/j. vetpar.2004.07.028

Perez, M., Rikihisa, Y., \& Wen, B. (1996). Ehrlichia canis-like agent from a man in Venezuela: antigenic and genetic characterization. Journal of Clinical Microbiology, 34(9), 2133-2139. doi: 10.1128/JCM. 34.9.2133-2139

Ramos, C. A. N., Ramos, R. A. N., Araujo, F. R., Guedes, D. S., Souza, I. I. F., Ono, T. M., Alves, L. C. (2009). Comparação de nested-PCR com o diagnóstico direto na detecção de Ehrlichia canis e Anaplasma platys em cães. Revista Brasileira de Parasitologia Veterinária, 18(1), 58-62. doi: 10.4322/ rbpv.018e1011

Ribeiro, C. M., Matos, A. C., Azzolini, T., Bones, E. R., Wasnieski, E. A., Richini-Pereira, V. B., Vidotto, O. (2017). Molecular epidemiology of Anaplasma platys, Ehrlichia canis and Babesia vogeli in stray dogs in Paraná, Brazil. Pesquisa Veterinária Brasileira, 37(2), 129-136. doi: 10.1590/s0100$736 \times 2017000200006$
Roura, X., Peters, I. R., Altet, L., Tabar, M. D., Barker, E. N., Planellas, M., Tasker, S. (2010). Prevalence of hemothropic mycoplasmas in healthy and unhealthy cats and dogs in Spain. Journal of Veterinary Diagnostic Investigation, 22(2), 270-274. doi: 10.1177/104063871002200219

Rufino, C. P., Moraes, P. H. G., Reis, T., Campos, R., Aguiar, D. C. F., Mcculloch, J. A.,... Gonçalves, E. C. (2013). Detection of Ehrlichia canis and Anaplasma platys DNA using multiplex PCR. Vector-Borne and Zoonotic Disease, 13(12), 846-850. doi: 10.1089/ vbz.2013.1303

Schnittger, L., Rodriguez, A. E., Florin-Christensen, M., \& Morrison, D. S. (2012). Babesia: a world emerging. Infection, Genetics and Evolution, 12, 1788-1809. doi: 10.1016/j.meegid.2012.07.004

Shaw, S. E., Binns, S. H., Birtles, R. J., Day, M. J., Smithson, R., \& Kenny, M. J. (2005). Molecular evidence of tick-transmitted infections in dogs and cats in the United Kingdom. Veterinary Record, 19(157), 645-648. doi: 10.1136/vr.157.21.645

Silva, G. C. F., Benitez, A. N., Girotto, A., Taroda, A., Vidotto, M. C., Garcia, J. L.,... Vidotto, O. (2012). Occurrence of Ehrlichia canis and Anaplasma platys in house hold dogs from northern Parana. Revista Brasileira de Parasitologia Veterinária, 21(4), 379385. doi: 10.1590/S1984-29612012005000009

Silva, J. N., Almeida, A. B. P. F., Sorte, E. C. B., Freitas, A. G., Santos, L. G. F., Aguiar, D. M., \& Sousa, V. R. F. (2010). Soroprevalência de anticorpos antiEhrlichia canis em cães de Cuiabá, Mato Grosso. Revista Brasileira de Parasitologia Veterinária, 19(2), 108-111. doi: 10.4322/rbpv.01902008

Simpson, R. M., Gaunt, S. D., Hair, J. A., Kocan, K. M., Henk, W. G., \& Casey, H. W. (1991). Evaluation of Riphicephalus sanguineus as a potential biologic vector of Ehrlichia platys. American Journal Veterinary Research, 52(9), 1537-1541.

Sousa, V. R., Bomfim, T. C. B., Almeida, A. B. P. F., Barros, L. A., Sales, K. G., Justino, C. H. S., \& Dalcin, L. (2009). Coinfecção pos Anaplasma platys e Ehrlichia canis em cães diagnosticada pela PCR. Acta Scientiae Veterinarie, 3(2), 281-283. doi: 10.22456/1679-9216.16348

Souza, B. G., Azevedo, W., Alvares, A. A. A., Balani, V. A., Balani, V. A., \& Leonardo, J. M. L. O. (2011). Prevalência de erliquiose em cães com trombocitopenia atendidos no hospital veterinárioCESUMAR. Anais do Encontro Internacional de Produção Científica. Guarapuava: PR, Brasil, 7. 
Recuperado de http://www.cesumar.br/prppge/ pesquisa/epcc2011/anais/bianca_gregorio_de_ souza.pdf

Trapp, S. M., Dagnone, A. S., Vidotto, O., Freire, R. L., Amude, A. M., \& Morais, H. S. A. (2009). Soroepidemiology of canine babesiosis and ehrlichiosis in a hospital population. Veterinary Parasitology, 140(3-4), 223-230. doi: 10.1016/j. vetpar.2006.03.030

Trapp, S. M., Messick, J. B., Vidotto, O., Jojima, F. S., \& Morais, H. S. A. (2006). Babesia gibsoni genotype Asia in dogs from Brazil. Veterinary Parasitology, 141(1-2), 177-180. doi: 10.1016/j.vetpar.2006.03. 030

Ueno, T.E.H.,Aguiar, D. M.,Pacheco, R.C., Richtzenhain, L. J., Ribeiro, M. G., Paes, A. C.,... Labruna, M. B. (2009). Ehrlichia canis em cães atendidos em hospital veterinário de Botucatu, São Paulo, Brasil. Revista Brasileira de Parasitologia Veterinária, 18(3), 57-61. doi: 10.4322/rbpv.01803010

Vieira, R. F. C., Biondo, A. W., Guimaraes, A. M. S., Santos, A. P., Santos, R. P., Dutra, L. H.,... Vidotto, O. (2011). Ehrlichiosis in Brazil. Revista Brasileira de Parasitologia Veterinária, 20(1), 01-12. doi: 10. 1590/S1984-29612011000100002

Vieira, R. F. C., Vidotto, O., Vieira, T. S. W. J., Guimarães, A. M. S., Santos, A. P., Nascimento, N. C.,... Messick, J. B. (2015). Molecular investigation of hemothropic mycoplasmas in human beigns, dogs and horses in a rural settlement in Southern Brazil. Revista do Instituto de Medicina Tropical, 57(4), 353-357. doi: 10.1590/S0036-46652015000400014
Vieira, T. S. W. J., Vieira, R. F. C., Nascimento, D. A. G., Tamekuni, K., Toledo, R. S., Chandrashekar, R.,... Vidotto, O. (2013). Serosurvey of tick-borne pathogens in dogs from urban and rural áreas from Parana state, Brazil. Revista Brasileira de Parasitologia Veterinária, 22(1), 104-109. doi: 10.1590/ S1984-29612013000100019

Vilela, J. A. R., Pires, M. S., Silva, C. B., Peixoto, M. P., Falqueto, A., Santos, H. A., Faccini, J. L. H. (2013). Alterações clínico-hematológicas da infecção por Babesia canis vogeli em cães do município de Seropédica, Rio de Janeiro, Brasil. Revista Brasileira de Medicina Veterinária, 35(1), 63-68.

Wen, B., Rikihisa,Y., Mott, J. M., Greene, R., Kim, H., Zhi, N.,... Bartsch, R. (1997). Comparison of nested PCR with immunofluorescent-antibody assay for detection of Ehrlichia canis infection dogs treated with doxycycline. Journal of Clinical Microbiology, 35(7), 1852-1855. doi: 10.1128/JCM.35.7.18521855.1997

Witter, R., Vecchi, S. N., Pacheco, T. A., Melo, A. L. T., Borsa, A., Sinkoc, A. L., Mendonça, A. J., \& Aguiar, D. M. (2013). Prevalência da erliquiose monocítica canina e anaplasmose trombocítica em cães suspeitos de hemoparasitose em Cuiabá, Mato Grosso. Semina: Ciências Agrárias, 34(6), 3811-3822. doi: 10.5433/1679-0359.2013v34n6Supl2p3811 